\section{Supreme Court nullifies patent ruling on living organisms}

\section{David Dickson reports on how a decision about the patentability of computer programs has implications for recombinant DNA technology}

IN a one-line decision that could have important implications for the future development of industrial processes using biological techniques, the US Supreme Court last week ordered an appeals court to reconsider its decision that living organisms can be patented.

Although the exact meaning of the decision is now being hotly debated in Washington, many feel that it is a signal from the Supreme Court that since there is no explicit mention in existing patent legislation that living organisms are covered, the issue of their patentability should be resolved in Congress, rather than by the courts.
In the short term, the court's action means that a number of patent applications for aspects of recombinant DNA techniques, the decisions on which have been held up pending a definitive outcome of the case in question, are likely to remain unresolved for a number of months to come.

The Supreme Court's decision was made on a dispute over a patent which had been applied for by a group of scientists working with the pharmaceutical manufacturer Upjohn Co. for a naturally occurring microorganism, Streptomyces vellosus, which the scientists had isolated, purified and were

\section{Lederberg suggests national foundation to exploit fruits of university research}

A National Research and Development Foundation, which would own and exploit the patent rights to inventions made in universities with federal grants money, but at an arm's length from the universities themselves, has been suggested by Professor Joshua Lederberg, president of Rockefeller University in New York. The suggestion has been made in a letter from Professor Lederberg, Nobel Prize-winner and until last month professor of genetics at Stanford University's School of Medicine, in a letter to Senator Gaylord Nelson, whose select committee on small business is currently holding hearings into federal patent policy.

In his letter, Professor Lederberg says that he does not believe the pursuit of proprietary gains to be the proper business of the staff of a university.

"The possibility of profit--especially when other funding is so tight -will be a distorting influence on open communication and on the pursuit of basic scholarship" he said.

Professor Lederberg continues: "On the other hand, the need to protect development investment for the exploitation of inventions is absolutely sound, and essential to the nation's economy. Such investments are typically much larger than the costs of the original research, and are comparable to the expected 'profits'when there is a pay-off.
"It should not be so difficult to reconcile these objectives, using the Research Corporation as a model. Set up an accountable, not-for-profit national $R \& D$ foundation, and vest all government-owned patents in it.

"NRDF will then enter the market, at arm's length, with licences etc. for the inventions it owns. The fees should first of all cover its operating expenses. Then it can use its profits and accumulated reserves to fund grants and contracts that will continue to further the practical applications of scientific discovery."

Professor Lederberg says that universities should not share in the licence fees except to the extent of their cost-sharing in the research that led to the invention, which would be assumed to be 10 per cent for routine cases.

Furthermore individuals should not, in principle, be rewarded for the results of work for which they were already receiving an academic salary, although neither should they be hindered in private arrangements, for the fruits of time and energy for which they were not on salary, and which are outside their normal academic duties.

"The financial and regulatory stresses on our private institutions are threatening their future existence. But patent-seeking is an inappropriate answer to these financial dilemmas," Professor Lederberg says.

David Dickson using to produce the antibiotic lincomycin.

The Patent and Trademark Office had initially turned the patent application down, primarily on the grounds that the patent laws as they now stand contain no indication that they are meant to cover living organisms; in support of this claim, it was argued that if Congress had meant such organisms to be covered, it would not have been necessary to pass a separate Plant Patent Act, as was done in 1930.

Last October, however, in a widely publicised verdict, the US Court of Customs and Patent Appeals reversed the decisions and allowed the patent. The court argued that despite the fact that microorganisms were alive, since they had become an important tool in chemical and pharmaceutical industries, "we do not see any reason to deprive it, or its creator or owner, of the protection and advantages of the patent system".

This ruling was subsequently used as the basis of a further decision by the appeals court in March of this year, which upheld a patent application made by an Indian microbiologist working for General Electric, Dr Ananda M. Chakrabarty, for a Pseudomonas bacterium which had been genetically altered to produce enzymes capable of degrading oil-and hence might provide a useful way of combating oil spills.

If the Supreme Court had upheld he ruling in the Upjohn case-the Justice Department has yet to decide whether to consult it in the second case, although this now seems increasingly likely-it would have set a precedent for granting a wide range of patent applications in the general field of biotechnology, including genetic engineering; and as one patent attorney said in Washington last week "the case would have been closed".

As it is, the court did not take a stand on the issue, but has virtually returned the debate to square one by referring it back to the appeals court, asking that it be re-examined "in the light of" a judgement handed down the previous week in a case over the patentability of computer programs.

In this case, a computer engineer had applied for a patent on a method for updating fire alarms in a chemical engineering process, the only novel aspect of which was the inclusion of a mathematical algorithm (which previous cases had established was not patentable on its own).

The application had initially been rejected by the patents officer on the ground that including an unpatentable step as a novel feature in an otherwise conventional manufacturing process did not make the process patentable. The CCPA disagreed, and reversed the 